\title{
The Effectiveness of Accompaniment Measures to Mother with Lbw In House after Kmc (Kangaroo Mother Care) Class on Improving Mother Skills
}

\author{
Retno Wahyuni ${ }^{1}$, Yosephine Maria Christina ${ }^{2}$, Lucky Herawati ${ }^{3}$ \\ ${ }^{1}$ STIKes Guna Bangsa Yogyakarta, Condongcatur, Depok, Sleman Yogyakarta 55283 Indonesia \\ ${ }^{2}$ RSUD Panembahan Senopati BantulBantul, Daerah Istimewa Yogyakarta 55714 Indonesia \\ ${ }^{3}$ Polytechnic of Health of Yogyakarta Sleman 55293 Indonesia \\ Corresponding Author: Retno Wahyuni
}

\begin{abstract}
In the Special Distrik of Yogyakarta (DIY) the Infant Mortality Rate (IMR) is 25 per 1000 live births, a common cause of infant mortality in DIY is the weight of low birth weight babies (LBW) and sepsis. Most $L B W$ is found in Sleman Regency. One of the treatments for $L B W$ is to take care of the kangaroo method. Problems that often occur in the field, postpartum mothers who have taken kangaroo mother care (KMC) classes do not do KMC again after home. The purpose of this study was to determine the effect of mentoring on postpartum mothers with LBW babies (dismature) at home on improving maternal skills in conducting KMC after participating in KMC classes.This study is quasi experiment, non equivalent control design, using postpartum maternal respondents with LBW (dismature), a sample of 38 people based on a minimum of experimental samples. The location of the study was in 2 hospitals in Sleman Regency. Determination of samples in each location was determined based on consecutive sampling. The instrument used to determine skill improvement is the operational standard procedure of KMC. The data obtained was then analyzed using the Wilcoxon Signed Rank Test and the Mann Whitney test with a significant level of 0.05. The results showed that there were significant differences in the improvement of maternal postpartum skills with LBW (dismature) in conducting KMC at home between the mentoring and non-mentoring groups (p-value 0,000).
\end{abstract}

Keywords: Skills, postpartum mothers, LBW, KMC

\section{Introduction}

Infant Mortality Rate (IMR) is a health indicator included in one of the targets of the Sustainable Development Goals (SDGs). SDGs target that every country that has committed in the SDGs must be able to reduce two-thirds of infant mortality in 2030. Infant Mortality Rate (IMR) in Indonesia is 23 per 1000 live births. AKB of the Special Region of Yogyakarta (DIY) is at 25 per 1000 live births. Common causes of infant mortality in DIY are the weight of low birth weight babies (LBW) and sepsis ${ }^{[1]}$.

Efforts in LBW care supported by complete facilities and infrastructure and trained human resources can reduce neonatal rates. In certain conditions and indications, LBW is in urgent need of an incubator, but care in the incubator is relatively expensive, in addition the use of incubators is considered to inhibit contact between mother and baby, resulting in the mother being less confident and skilled in caring for her baby. To reduce barriers to eye contact between mother and baby so that mothers can be confident and skilled in treating LBW, one of which is the Kangaroo Care Method ${ }^{[2]}$.

One of the treatments for infants with LBW is to do the Kangaroo Mother Care (KMC) and keep doing it at home. Research in Addis Abeba showed the number of infants who died in the KMC group was 22.5\% while in the non-KMC group it was 38\% ( $\mathrm{p}<0.05$ ). From the above literature it is clear that KMC is useful in preventing neonatal death ${ }^{[3]}$.

Some of the benefits of KMC are that it can stabilize the temperature, respiratory rate, and baby's heart rate faster than babies treated in an incubator, babies in KMC feel comfortable and warm in their arms so that vital signs can stabilize faster ${ }^{[4]}$. In the Bera A, et al. (2014) study that motor and mental growth and development in LBW with KMC was far better than LBW with conventional (incubator) care for LBW until 12 months of age ${ }^{[5]}$. While based on the study of Astuti, Mutoharoh \& Priyanti (2016) stated that more weight gain in LBW treated with KMC compared with those not treated with KMC. Whereas in another study stated that maternal motivation increased in doing Kangaroo Method Care after being given counseling in the form of counseling regarding $\mathrm{KMC}^{[2]}$. 
The effect of home planning management focusing on KMC on the skills of mothers doing KMC at home stated that the effect of implementing home planning applied from the start and during treatment showed more results in the intervention group. Of the 15 respondents in the intervention group, there were 8 respondents who were skilled in KMC after the KMC focused planning was conducted compared to respondents in the control group. In the control group, it turned out that the return planning focused on Kangaroo Method Treatment showed no results. Therefore, the need to implement planning for returning KMC was followed up to the house to monitor the skills of the mother in conducting KMC while at home ${ }^{[6]}$.

Based on some previous studies, it has been shown that no intervention has been carried out by providing assistance to the home when the mother has been discharged from the hospital to improve maternal skills and increase the baby's weight. The results of a preliminary study conducted on October 6, 2017 obtained data on the highest number of LBW in Sleman Regency as many as 823 babies. Therefore, the researchers wanted to get information about mentoring on improving the skills of postpartum mothers at home in conducting KMC in Sleman Regency.

\section{Method}

This type of research is Quasi Experiment with Non Equivalent Control Design research design. Respondents studied were postpartum mothers with LBW (dismature). To be able to see the achievement of improvement in skills carried out mentoring 1 time and post-test 1 time after 2 weeks in the mentoring group and post-test 1 time after 3 weeks in the group without assistance. Mentoring is a mentoring group and without assistance as a comparison group.

The number of postpartum maternal populations during the past 1 year (Jan - Dec 2016) in Hospital A was 187 mothers postpartum (dismature), whereas in Hospital B there were 68 mothers postpartum (dismature). The sample used in this study amounted to 38 mothers postpartum (dismature) using the Lemeshow calculation. The location of this study was conducted at Sleman Hospital (Hospital A) and Condongcatur Hospital (Hospital B) which were in Sleman Regency for approximately 4 months (April-July 2018).

The independent variable in this study is to provide assistance and without assistance. The respondents of the mentoring group were 19 people and the group without assistance 19 people. By using consecutive sampling technique. The dependent variable is the postpartum maternal skills with LBW babies in caring for the kangaroo method at home as measured by the operational standard procedure of KMC.

he data obtained were analyzed using the Wilcoxon Signed Rank Test and Mann Whitney with a significant level of 0.05 . This research was approved by the Respati Yogyakarta Health Research Ethics Committee at the Faculty of Health Sciences on April 4, 2018 with No: 073.1 / UNRIYO / PL / IV / 2018.

\section{Result}

Most of the respondents in the age group in the old reproductive category were 10 respondents, while in the majority control group there were 13 healthy respondents, 26 respondents were based on education and 32 respondents were parity.

Table 2. The Characteristics of Respondents

\begin{tabular}{|c|c|c|c|c|}
\hline \multirow{2}{*}{$\begin{array}{c}\text { Characteristics of LBW } \\
\text { Babies }\end{array}$} & \multicolumn{4}{|c|}{ LBW Infant Group } \\
\cline { 2 - 5 } & $\mathrm{N}$ & $\%$ & $\mathrm{~N}$ & $\%$ \\
\cline { 2 - 5 } & & & & \\
\hline Gender & 11 & 28,2 & 9 & 23,1 \\
Male & 8 & 20,5 & 10 & 25,6 \\
\hline Female & & & & 7,7 \\
\hline Weight (pre-test) & 5 & 12,8 & 3 & 41,0 \\
\hline 1500-2000gr & 14 & 35,9 & 16 & \\
2050-2450gr & & & & 4,6 \\
\hline Weight (post-test) & 2 & 5,1 & 1 & \\
\hline 2050-2450gr & 17 & 43,6 & 18 & \\
\hline >2500gr & & & & \\
\hline
\end{tabular}

\section{Implementation of Mentoring for Post-Maternal Mothers with LBW at Home}

When conducting assistance, some respondents showed their sincerity in doing the Kangaroo Mother Care (KMC) while at home and attempting to comply with the Standard Operational Procedure and that had been done while still in the hospital. However, some respondents still seemed hesitant in conducting KMC at home. 


\section{Average Maternal Skills Before and After Assistance in Experimental and Control Groups}

After being analyzed with the Wilcoxon Signed Rank Test, with a significant level of 0.05, the results of each group had a significance value of $0,000(\mathrm{p}<0.05)$ and it was found that there were significant differences in postpartum maternal skills before and after both groups experiment and control group.

Table 2. Average Mother Skills Using the Wilcoxon SRT Test

\begin{tabular}{|c|c|c|c|}
\hline & \multicolumn{3}{|c|}{ Skills Value Pre-test and Post-test } \\
\hline & $\mathrm{N}$ & Mean & $P$ \\
\hline Experiment group & 19 & 17,82 & 0,000 \\
\hline Control group & 19 & 16,74 & 0,000 \\
\hline
\end{tabular}

\section{The Different of Mother Skills on Implementation Kangaroo Mother Care in Experimental Groups and Control Groups}

The results of the Mann Whitney test on differences in maternal skills for the experimental group and the control group obtained a $\mathrm{p}$ value of $0,000(\mathrm{p}<0.05)$. These results prove that there are significant median differences between the 2 groups. In other words there are significant differences between the mentoring and non-mentoring groups.

Table 3. Different Results of Mother Skills Using the Mann Whitney Test

\begin{tabular}{|c|c|c|c|}
\hline & \multicolumn{3}{|c|}{ Skill Differences } \\
\hline Experiment & $\mathrm{N}$ & Mean & $p$ \\
\hline Control & 19 & 3,42 & 0,000 \\
\hline
\end{tabular}

\section{Discussion}

This research was conducted to find out the differences in the skills of mothers doing kangaroo method care at home between those who were assisted and without assistance in Sleman Yogyakarta. The sample in this study was 38 people consisting of 19 respondents in the experimental group and 19 respondents in the control group.

In this study the two variables were tested for data normality using the Shapiro Wilk test because the number of samples in this study was less than 50. From the results of the normality test in the experimental group showed a significance value of $0,000(\mathrm{p}<0.05)$ and in the control group had a significance value of 0.003 $(\mathrm{p}<0.05)$, which means that the two data variables are abnormally distributed.

Test analysis to determine the average value of post-partum maternal skills using the Wilcoxon Signed Rank Test because the two data variables are abnormally distributed. The results of the study showed that there were differences in the value of the skills of the mothers in taking care of the kangaroo method in the experimental group before and after being given assistance. This can be seen from the mean value when done in the experimental group 17.82 and the control group 16.74. And the significance values of the two groups amounted to 0,000 ( $\mathrm{p}<0.05)$, it can be seen that there were significant differences from the results of the pre-test and post-test skills in the experimental group and the control group.

In the research of Sri Rahayu stated that there were differences in the independence of mothers to care for the kangaroo method between groups given assistance and the Kangaroo Method and Control Group Care module with $\mathrm{p}$ value $<0.001$. Mothers who are given assistance and modules tend to be more independent in carrying out kangaroo method care after returning from the hospital ${ }^{(7)}$.

Mothers who are given assistance and modules tend to be more independent in carrying out kangaroo method treatments. The results of this study also support the study of Bang et al. in Gadchiroli, India which states that "home based neonatal care" can reduce neonatal morbidity to half ${ }^{(8)}$.

Pratomo (1995) said that the kangaroo method needs to be socialized to mothers so that the mothers will know the purpose and benefits of the kangaroo method, because if the mother is identified as a kangaroo that can hold her baby optimally the optimal temperature is $36.5-37.5^{\circ} \mathrm{C}$ obtained by direct contact between baby's skin and mother's skin. Mother's temperature is an efficient and inexpensive source of heat and can provide warmth to the baby, close contact so that interactions between mother and baby will increase the psychomotor development of the baby as a reaction to the sensory stimulation that the mother gives to her baby (9).

From the results of the Mann Whitney test with $\mathrm{p}$-value $\neg$ equal to $0,000(\mathrm{p}<0.05)$ which proves that there are differences in skills in the group given treatment and groups that are not given treatment. Mentoring and without assistance can improve maternal skills to care for LBW babies after returning from the hospital. The results of this study are supported by research by Wobil \& Yakubu in Ghana, that mothers who have LBW babies since at the hospital mothers were interviewed to ensure their knowledge of KMC, and practices 
regarding KMC, $95.5 \%$ thought $\mathrm{KMC}$ was beneficial to them and $96.0 \%$ beneficial for babies and $98.0 \%$ would recommend $\mathrm{KMC}$ for other mothers and $71.8 \%$ willing to practice KMC outdoors ${ }^{(10)}$.

Furthermore, following up on home visits, results were $99.5 \%$ (181 respondents) still practicing either intermittent or continuous KMC. The mother's knowledge about KMC is low at the beginning, with the intervention of the mother being trained $\mathrm{KMC}$ in the hospital and at home the mother is more stable in doing KMC so that the baby's weight becomes optimal. This means that with the support of officers and providing information about KMC continuously will improve the ability of mothers to care for their babies so that it will increase self-confidence and be more independent in caring for their babies ${ }^{(10)}$.

\section{Conclusion}

There was a significant difference between the mentoring and non-mentoring groups in postpartum mothers with LBW (dismature) at home after the kangaroo mmother care class.

\section{Acknowledgements}

The researcher thanked to the leaders of the two hospitals in Sleman Regency for assisting the researchers in collecting data, and the STIKes Mitra Husada Medan Foundation which had provided financial support in completing this research.

\section{References}

[1]. Dinas Kesehatan DI Yogyakarta. Profil Kesehatan Daerah Istimewa Yogyakarta 2015. ... Heal Care [Internet]. $2015 ; 8(6): 719-27$. Available http://pediatrics.aappublications.org/content/108/3/719.abstract\%5Cnhttp://www.depkes.go.id/resources/download/pusdatin/profilkesehatan-indonesia/profil-kesehatan-indonesia-

2012.pdf\%5Cnhttp://www.pubmedcentral.nih.gov/articlerender.fcgi?artid=1718345\&too

[2]. Setiawati, Rini. Jurnal Kesehatan Masyarakat THE EFFECT OF COUNSELING FOR MOTIVATING MOTHER TO DO THE. Pengaruh Konseling Terhadap Motiv Ibu Melakukan Perawatan Metod Kanguru Pada Bayi Berat Lahir Rendah. 2016;11(2).

[3]. Margaretha SL. Metoda Kanguru pada Perawatan Bayi Berat Lahir Rendah. Sari Pediatr. 2006;8(3):181-7.

[4]. Suradi R, Yanuarso PB. Metode kanguru sebagai pengganti inkubator untuk bayi berat lahir rendah. Sari Pediatr. 2000;2(1):29-35.

[5]. Bera A, Ghosh J, Singh AK, Hazra A, Mukherjee S, Mukherjee R. Effect of kangaroo mother care on growth and development of low birthweight babies up to 12 months of age: a controlled clinical trial. Acta Paediatr [Internet]. 2014;103(6):643-50. Available from: http:https://doi.org/10.1111/apa.12618

[6]. Nursinih. Pengaruh Pelaksanaan Perencanaan Pulang Berfokus Perawatan Metode Kanguru (KMC) Terhadap Keterampilan Ibu Melakukan KMC Di Rumah. Pengaruh Pelaks Perenc Pulang Berfokus Perawatan Metod Kanguru Terhadap Keterampilan Ibu Melakukan KMC Di Rumah. 2015;

[7]. Sari A, Banjrmasin M. Dinamika Kesehatan, Vol.5 No.2 Desember 2015 Rahayu et al., Hubungan Usia Ibu dengan bayi Berat... 2015;5(2):0-9.

[8]. Rahayu S, Runjati, Ariyanti I. Pengaruh Pendampingan dan Pemberian Modul Kangaro Mother Care terhadap Kemandirian Ibu Nifas Merawat BBLR di Rumah. J Ilm Bidan. 2016;I(3):55-60.

[9]. Bergh AM, De Graft-Johnson J, Khadka N, Om'Iniabohs A, Udani R, Pratomo H, et al. The three waves in implementation of facility-based kangaroo mother care: A multi-country case study from Asia. BMC Int Health Hum Rights [Internet]. 2016;16(1). Available from: http://dx.doi.org/10.1186/s12914-016-0080-4

[10]. Nguah SB, Wobil PNL, Obeng R, Yakubu A, Kerber KJ, Lawn JE, et al. Perception and practice of Kangaroo Mother Care after discharge from hospital in Kumasi, Ghana: A longitudinal study. BMC Pregnancy Childbirth [Internet]. 2011;11(1):99. Available from: http://www.biomedcentral.com/1471-2393/11/99

Retno Wahyuni. "The Effectiveness of Accompaniment Measures to Mother with Lbw In House after Kmc (Kangaroo Mother Care) Class on Improving Mother Skills" .IOSR Journal of Nursing and Health Science (IOSR-JNHS), vol. 8, no.01, 2019, pp. 68-71. 